Seminar Nasional Teknologi Informasi dan Kedirgantaraan (SENATIK)

Vol. II, 26 November 2016, ISSN: 2528-1666

\title{
BAWANG PUTIH, BAYAM DAN GARAM SEBAGAI ENERGI ALTERNATIF BATERAI
}

\author{
Benedictus Mardwianta \\ Sekolah Tinggi Teknologi Adisutjipto Yogyakarta. \\ Jl Janti Blok R Lanud Adisutjipto, Yogyakarta \\ aries2144@yahoo.com
}

\begin{abstract}
The use of a battery to get the electricity demand in Indonesia is still needed. Inside there is a liquid electrolyte battery that serves as an energy source battery. In this study, the source of energy used is garlic, spinach and salt. All energy sources are mixed into three compositions based on a predetermined mass ratio. The purpose of this study was to determine the effect of the electrolyte of garlic, spinach and salt as an alternative source of electrical energy in the dry battery. The composition of the material with a mass percentage used are: a. Composition I is $20 \%$ garlic, raw spinach $40 \%$ and $40 \%$ salt; b. Composition II was $40 \%$ garlic, raw spinach $20 \%$ and $40 \%$ salt; c. Composition III was $40 \%$ garlic, raw spinach $40 \%$ and $20 \%$ salt. Results from this research that a battery with composition III has the highest voltage of 1.484 volt. The battery with the composition III has the highest electric current of $0.656 \mathrm{~mA}$. Multiplying the voltage by the electric current will generate electric power. The electrical power to the composition III is $0.974 \mathrm{~mW}$. The salt is not very influential on electric power because the salt is neutral.
\end{abstract}

Keywords: bawang putih, bayam, garam, tegangan, daya

\section{Pendahuluan}

Dalam kehidupan sehari-hari, arus listrik yang dihasilkan dari suatu reaksi kimia dalam sel volta banyak kegunaannya, seperti untuk radio, kalkulator, televisi, kendaraan bermotor, dan lain-lain. Sel volta dalam kehidupan sehari-hari ada dalam bentuk Aki atau Baterai Di antara berbagai sel, sel timbal (aki) telah digunakan sejak 1915. Berkat sel ini, mobil atau sepeda motor dapat mencapai mobilitasnya, dan akibatnya menjadi alat transportasi terpenting saat ini. Baterai timbal dapat bertahan kondisi yang ekstrim (temperatur yang bervariasi, shock mekanik akibat jalan yang rusak, dll) dan dapat digunakan secara kontinu beberapa tahun. Dalam baterai timbal, elektroda negatif adalah logam timbal $(\mathrm{Pb})$ dan elektroda positifnya adalah timbal yang dilapisi timbal oksida $\left(\mathrm{PbO}_{2}\right)$, dan kedua elektroda dicelupkan dalam larutan elektrolit asam sulfat $\left(\mathrm{H}_{2} \mathrm{SO}_{4}\right)$ [1]. Penggunaan material timbal dapat mencemari lingkungan. Oleh sebab itu diperlukan bahan lain yang lebih ramah lingkungan.
Pada baterai kering terdapat elektrolit yang berupa asam kuat seperti asam sulfat. Baterai listrik adalah alat yang terdiri dari dua atau lebih sel elektrokimia yang mengubah energi kimia yang tersimpan menjadi energi listrik. Tiap sel memiliki kutub positif (katoda) dan kutub negatif (anoda). Kutub yang bertanda positif menandakan bahwa memiliki energi potensial yang lebih tinggi daripada kutub bertanda negatif. Kutub bertanda negatif adalah sumber elektron yang ketika disambungkan dengan rangkaian eksternal akan mengalir dan memberikan energi ke peralatan eksternal. Ketika baterai dihubungkan dengan rangkaian eksternal, elektrolit dapat berpindah sebagai ion di dalamnya, sehingga terjadi reaksi kimia pada kedua kutubnya. Perpindahan ion dalam baterai akan mengalirkan arus listrik keluar dari baterai sehingga menghasilkan kerja[1]. Meski sebutan baterai secara teknis adalah alat dengan beberapa sel, sel tunggal juga umumnya disebut baterai.

Baterai primer (satu kali penggunaan) hanya digunakan sekali dan dibuang; material elektrodanya 
tidak dapat berkebalikan arah ketika dilepaskan. Penggunaannya umumnya adalah baterai alkaline digunakan untuk senter dan berbagai alat portabel lainnya. Baterai sekunder (Baterai dapat diisi ulang) dapat digunakan dan diisi ulang beberapa kali; komposisi awal elektroda dapat dikembalikan dengan arus berkebalikan. Contohnya adalah baterai timbal-asam pada kendaraan dan baterai ion litium pada elektronik portabel.

Baterai terdiri dari berbagai bentuk dan ukuran dari sel berukuran mini untuk alat bantu pendengaran dan jam tangan hingga bank baterai seukuran ruangan yang bisa memberikan tenaga untuk pertukaran telepon dan pusat data komputer. Baterai memiliki energi spesifik (energi per satuan massa) yang jauh lebih rendah daripada bahan bakar biasa seperti bensin. Namun, biasanya hal ini ditutup dengan efisiensi motor listrik yang lebih tinggi daripada motor bakar dalam menghasilkan kerja mekanik. Baterai mengubah energi kimia langsung menjadi energi listrik. Baterai terdiri dari sejumlah sel volta. Tiap sel terdiri dari 2 sel setengah yang terhubung seri melalui elektrolit konduktif yang berisi anion dan kation. Satu sel setengah termasuk elektrolit dan elektroda negatif, elektroda yang di mana anion berpindah; sel-setengah lainnya termasuk elektrolit dan elektroda positif di mana kation berpindah. Reaksi redoks akan mengisi ulang baterai. Kation akan tereduksi (elektron akan bertambah) di katoda ketika pengisian, sedangkan anion akan teroksidasi (elektron hilang) di anoda ketika pengisian. Ketika digunakan, proses ini dibalik. Elektrodanya tidak bersentuhan satu sama lain, namun terhubung via elektrolit. Beberapa sel menggunakan elektrolit yang berbeda untuk tiap sel setengah. Sebuah separator dapat membuat ion mengalir di antara sel-setengah dan bisa menghindari pencampuran elektrolit. Tiap sel setengah memiliki gaya gerak listrik (GGL), ditentukan dari kemampuannya untuk menggerakkan arus listrik dari dalam ke luar sel. GGL bersih sebuah sel perbedaan GGL masing-masing sel setengah. Para pakar kesehatan secara konsisten melakukan penggalian informasi khasiat bawang putih melalui penelitian farmakologi laboratoris yang sistematis [2]. Tahapan pengujian, penelitian, dan pengembangan secara sistematis perlu dilakukan agar pemanfaatan dan khasiat bawang putih dapat dipertanggungjawabkan secara ilmiah [2], bukan sekedar pengetahuan yang diperoleh secara turuntemurun. Pembuatan catatan atau dokumentasi ilmiah atas hasil penelitian tersebut dilakukan agar dapat terus dimanfaatkan dan dikembangkan oleh generasi di masa depan. Penelitian farmakologi tentang bawang putih telah banyak dilakukan, tidak hanya secara in vivo (dengan hewan percobaan) tetapi juga in vitro (dalam tabung kultur). Hal ini ditempuh untuk membuktikan khasiat dan aktivitas biologi dari senyawa aktif bawang putih, sekaligus dosis dan kemungkinan efek sampingnya. Berbagai penelitian yang telah dikembangkan untuk mengeksplorasi aktivitas biologi umbi bawang putih yang terkait dengan farmakologi, antara lain sebagai antidiabetes, anti-hipertensi, anti-kolesterol, antiatherosklerosis, anti-oksidan, anti-agregasi sel platelet, pemacu fibrinolisis, anti-virus, antimikrobia, dan anti-kanker [3]. Menurut ahli nutrisi yang berasal dari kanada, bayam merupakan suatu sumber utama dari natrium dan magnesium yang merupakan dua elektrolit penting untuk menjaga kesehatan manusia. Selain memiliki kandungan elektrolit, bayam juga memiliki berbagai kandungan vitamin dan mineral yang dibutuhkan oleh tubuh kita, yaitu Vitamin K, Vitamin A, folat, Vitamin B2, Vitamin B6, Vitamin E, kalsium, besi, dan Vitamin $\mathrm{C}$ [3]. Natrium klorida tidak mengubah warna lakmus merah menjadi biru atau lakmus biru menjadi merah berarti larutannya bersifat netral. Di laboratorium garam dapur dapat dibuat dari reaksi antara asam dan basa. Reaksi pembentukan garam dari asam dan basa disebut penetralana atau reaksi netralisasi. Sifatsifat garam di antaranya sebagai berikut mempunyai rasa asin, dapat menghantarkan arus listrik, tidak mengubah warna kertas lakmus merah maupun biru, memiliki pH netral sekitar 7, terbentuk dari sisa asam dengan sisa basa, senyawa yang terdiri dari unsur logam dan non logam, misalnya $\mathrm{NaCI}$ di mana natrium (Na) termasuk logam dan clorida (CI) termasuk unsur non logam [4]. Berbagai kandungan yang terdapat dalam bayam, memiliki berbagai fungsi kesehatan bagi tubuh kita antara lain adalah kandungan vitamin $\mathrm{K}$ sangat baik bagi kesehatan tulang, menurut penelitian yang telah dilakukan, asupan vitamin $\mathrm{K}$ bisa mengurangi kemungkinan terjadinya patah tulang dengan cara meningkatkan kerapatan tulang, hal tersebut terjadi karena tubuh kita menggunakan vitamin $\mathrm{K}$ ketika membentuk tulang. Selain vitamin $\mathrm{K}$, bayam juga mengandung kalsium yang baik untuk tulang, meskipun hanya sedikit dan tetap harus didukung dengan makan makanan lain yang mengandung kalsium. Bayam merupakan salah satu 
makanan yang banyak mengandung besi, besi sendiri merupakan komponen penting dalam pembentukan darah, sehingga memakan bayam direkomendasikan untuk mencegah anemia[5].

\section{Metode Penelitian}

\subsection{Diagram Alir Penelitian}

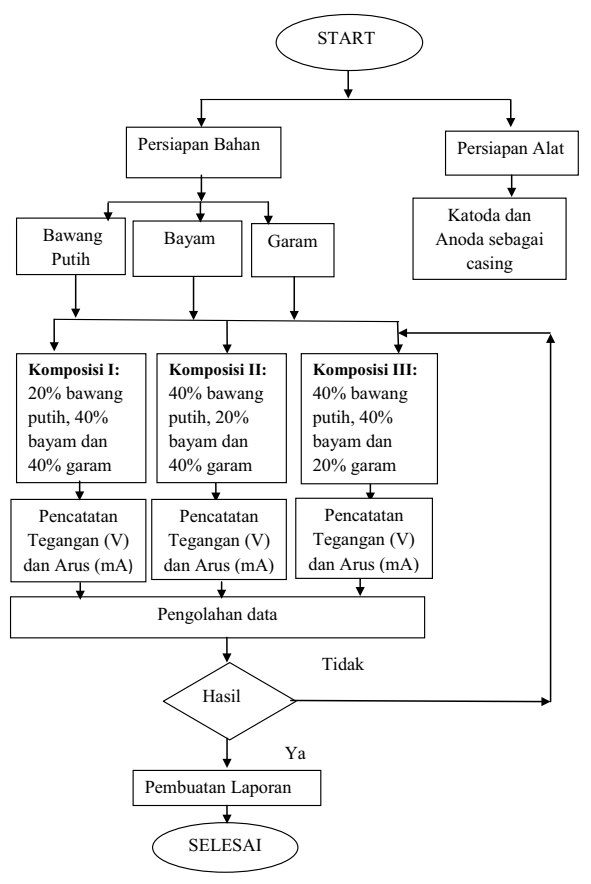

Metode penelitian pada baterai kering ini meliputi persiapan bahan dan persiapan alat.

\subsection{Persiapan Bahan}

1. Bawang putih

Bawang putih ditumbuk dengan halus kemudian hasil tumbukannya digunakan sebagai elektrolit pada baterai.

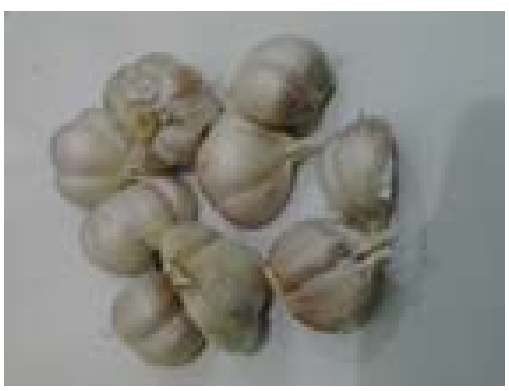

Gambar 1 Bawang putih

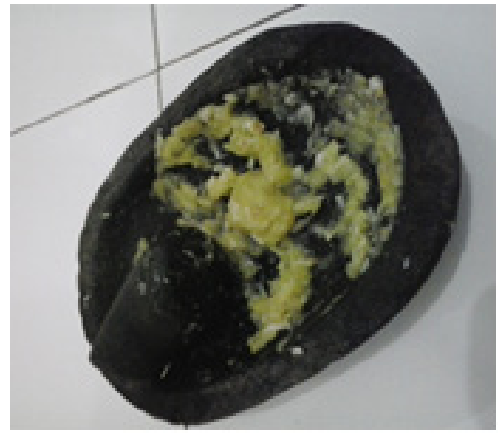

Gambar 2 Bawang yang sudah halus

2. Bayam mentah

Bayam mentah ditumbuk dengan halus kemudian hasil tumbukannya digunakan sebagai elektrolit pada baterai.

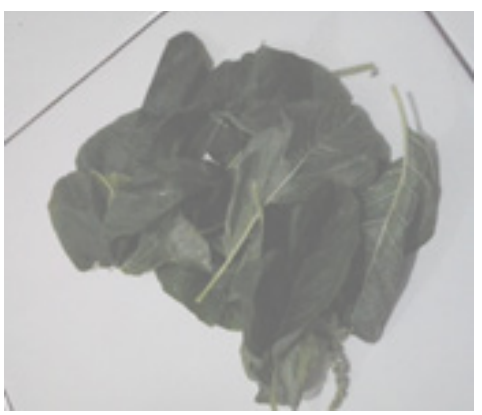

Gambar 3 Bayam

3. Garam

Garam diberikan sedikit air sehingga berubah menjadi larutan dan dapat digunakan sebagai campuran elektrolit pada baterai.

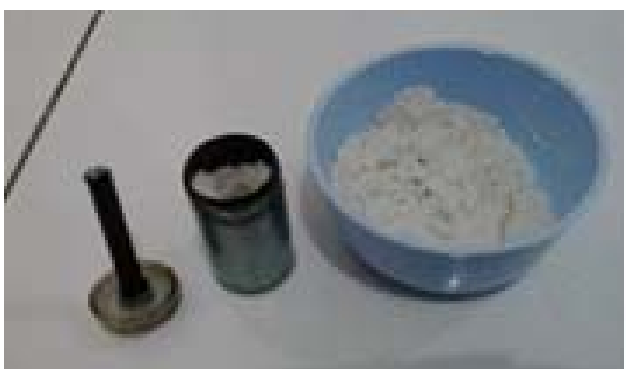

Gambar 4 Garam yang sudah halus

\subsection{Persiapan Alat}

1. Membersihkan batang karbon sebagai katoda baterai dan mengecek kondisi agar layak untuk penelitian. 


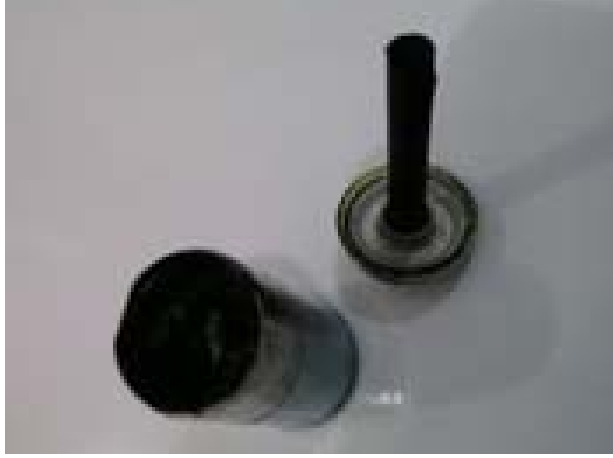

Gambar 5 Mengecek kondisi katoda

2. Mengecek kondisi seng sebagai anoda jangan ada korosi karena akan menghambat laju energi listrik.

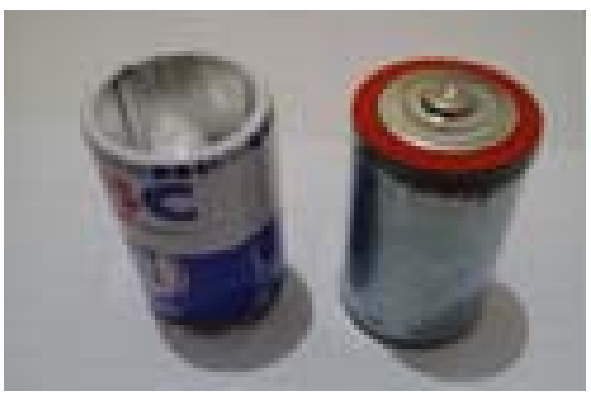

Gambar 6 Kondisi Seng Baterai

\subsection{Komposisi Bahan}

Setelah melakukan persiapan bahan dan persiapan alat maka dapat mengatur komposisi bahan berdasarkan massa bahan, yaitu:

1. Komposisi I: $20 \%$ bawang putih, $40 \%$ bayam mentah dan $40 \%$ garam

2. Komposisi II: $40 \%$ bawang putih, $20 \%$ bayam mentah dan $40 \%$ garam

3. Komposisi III: $40 \%$ bawang putih, $40 \%$ bayam mentah dan $20 \%$ garam

\section{3.1. Rumus Matematika}

Dalam mengukur daya listrik yang dihasilkan baterai dapat menggunakan persamaan (1).

$$
P=V x I
$$

Di mana : P adalah daya listrik $(\mathrm{mW})$ $\mathrm{V}$ adalah tegangan listrik (V) I adalah arus listrik (mA)

\subsubsection{Pencatatan Data}

Melakukan pencatatan data pada tiap-tiap komposisi. Pencatatan data yaitu tegangan dan arus listrik.

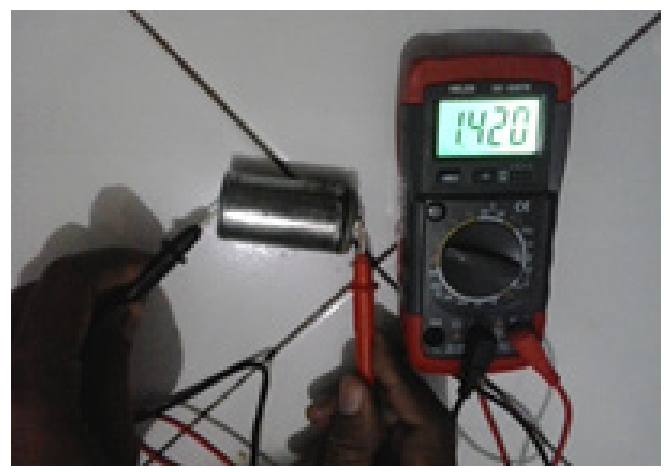

Gambar 7 Pencatatan Data

\section{3.4 Pengolahan Data}

Setelah semua data diperoleh maka data dapat diolah dan dapat diambil kesimpulan pada penelitian ini.

Pada komposisi I, daya yang diperoleh sebesar :

$$
\begin{aligned}
& \mathrm{P}=\mathrm{V} \times \mathrm{I} \\
& \mathrm{P}=1,477 \text { Volt } \times 0,582 \mathrm{~mA} \\
& \mathrm{P}=0,86 \mathrm{~mW}
\end{aligned}
$$

Pada komposisi II, daya yang diperoleh sebesar :

$$
\begin{aligned}
& \mathrm{P}=\mathrm{V} \times \mathrm{I} \\
& \mathrm{P}=1,439 \text { Volt } \times 0,469 \mathrm{~mA} \\
& \mathrm{P}=0,675 \mathrm{~mW}
\end{aligned}
$$

Pada komposisi III, daya yang diperoleh sebesar :

$$
\begin{aligned}
& \mathrm{P}=\mathrm{V} \times \mathrm{I} \\
& \mathrm{P}=1,484 \text { Volt } \times 0,656 \mathrm{~mA} \\
& \mathrm{P}=0,974 \mathrm{~mW}
\end{aligned}
$$

\section{Hasil dan Pembahasan}

Sebelum mengetahui komposisi dari ketiga campuran dari bahan elektrolit yaitu bawang putih, bayam dan garam, terlebih dahulu mengukur masing-masing bahan elektrolit yang akan digunakan pada komposisi. Hasil yang diperoleh yaitu untuk bahan elektrolit bawang putih yang sudah dihaluskan menghasilkan tegangan 1,42 Volt. Bahan elektrolit dari sayuran hijau yaitu bayam menghasikan tegangan 1,198 Volt dan bahan elektrolit dari garam yang sudah diberi sedikit air menghasilkan tegangan 1,556 Volt. Pembacaan tegangan listrik baterai menggunakan alat ukur 
tegangan bernama multimeter. Multimeter yang digunakan yaitu multimeter digital agar lebih mudah dalam pembacaannya daripada multimeter analog. Hasil dari tegangan yang diperoleh dapat dibuat dalam bentuk tabel seperti di bawah ini yaitu tabel 1. Langkah selanjutnya adalah mencampur ketiga bahan elektrolit tersebut yaitu bawang putih, bayam dan garam sesuai dengan komposisi yang diinginkan. Pada komposisi I yaitu 20\% bawang putih, 40\% bayam dan $40 \%$ garam. Pada komposisi II yaitu $40 \%$ bawang putih, $20 \%$ bayam dan $40 \%$ garam. Pada komposisi III yaitu $40 \%$ bawang putih, $40 \%$ bayam dan $20 \%$ garam. Hasil dari penelitian ini yaitu baterai dengan komposisi III mempunyai tegangan listrik paling tinggi sebesar 1,484 Volt, kemudian komposisi I sebesar 1,477 Volt dan tegangan listriknya paling rendah adalah komposisi II sebesar 1,439 Volt. Arus listrik penelitian ini yaitu baterai dengan komposisi III mempunyai arus listrik paling tinggi sebesar 0,656 mA, kemudian komposisi I sebesar 0,582 $\mathrm{mA}$ dan arus listriknya paling rendah adalah komposisi II sebesar 0,469 $\mathrm{mA}$. Dari perkalian tegangan dengan arus listrik akan menghasilkan daya listrik. Daya listrik terbesar pada komposisi III yaitu $0,974 \mathrm{~mW}$, pada komposisi I yaitu $0,860 \mathrm{~mW}$ dan daya terkecil pada komposisi II yaitu $0,675 \mathrm{~mW}$. Oleh sebab itu campuran pada komposisi III yang banyak mengandung bawang putih dan bayam banyak mengandung asam. Untuk garam tidak terlalu berpengaruh pada daya listrik karena garam bersifat netral.

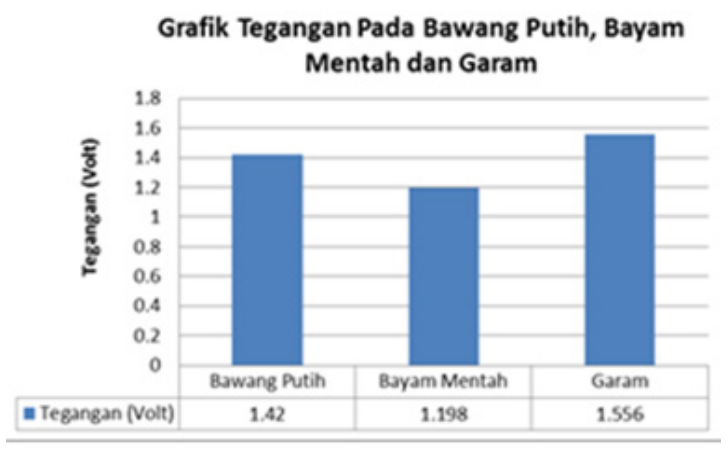

Gambar 8 Grafik Tegangan Pada Elektrolit

Tabel 1 Tegangan Elektrolit

\begin{tabular}{|l|l|l|l|}
\hline Elektrolit & Bawang Putih & Bayam & Garam \\
\hline Tegangan (Volt) & 1,42 & 1,198 & 1,556 \\
\hline
\end{tabular}

Setelah mencampur setiap baterai sesuai dengan komposisinya masing-masing, maka untuk memperoleh hasil data tegangan yang lebih akurat dibuat lima baterai untuk setiap komposisi. Hasil tegangan yang dihasilkan dari kelima baterai tersebut sesuai Tabel 2.

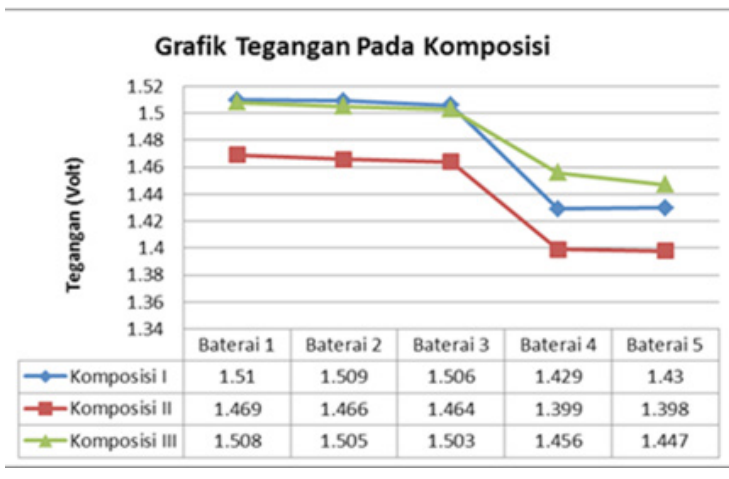

Gambar 9 Grafik Tegangan Pada Komposisi

Tabel 2 Tegangan Pada Komposisi

\begin{tabular}{|c|c|c|c|}
\hline Baterai & Komposisi I & Komposisi II & Komposisi III \\
\hline Baterai 1 & 1,51 & 1,469 & 1,508 \\
\hline Baterai 2 & 1,509 & 1,466 & 1,505 \\
\hline Baterai 3 & 1,506 & 1,464 & 1,503 \\
\hline Baterai 4 & 1,429 & 1,399 & 1,456 \\
\hline Baterai 5 & 1,43 & 1,398 & 1,447 \\
\hline
\end{tabular}

Setelah tabel 2 dibuat maka dapat dibuat juga grafik tegangan pada tiap-tiap baterai untuk setiap komposisi seperti pada gambar 9. Tujuan dibuatnya grafik ini adalah untuk mempermudah pembacaan tegangan.

Untuk penggunaan baterai biasanya disusun secara seri, sehingga tegangan total yang dihasilkan baterai adalah hasil penjumlahan banyaknya baterai dalam alat yang digunakan contohnya pada senter atau lampu. Total tegangan lima baterai pada tiaptiap komposisi dapat ditabelkan seperti tabel 3 di bawah ini.

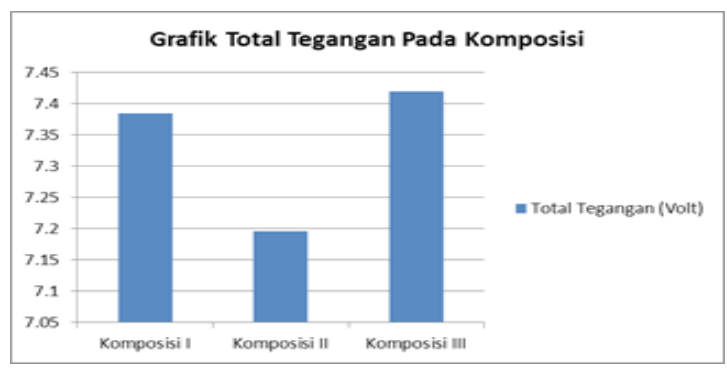

Gambar 10 Grafik Total Tegangan Pada Komposisi 
Setelah tabel 3 dibuat maka dapat dibuat juga grafik total tegangan lima baterai pada komposisi seperti pada gambar 10. Tujuan dibuatnya grafik ini adalah untuk mempermudah pembacaan total tegangan pada komposisi.

Tabel 3 Total Tegangan Pada Komposisi

\begin{tabular}{|c|c|c|c|}
\hline Elektrolit & $\begin{array}{c}\text { Komposisi } \\
\text { I }\end{array}$ & $\begin{array}{c}\text { Komposisi } \\
\text { II }\end{array}$ & $\begin{array}{c}\text { Komposisi } \\
\text { III }\end{array}$ \\
\hline $\begin{array}{c}\text { Total Tegangan } \\
\text { (Volt) }\end{array}$ & 7,384 & 7,196 & 7,419 \\
\hline
\end{tabular}

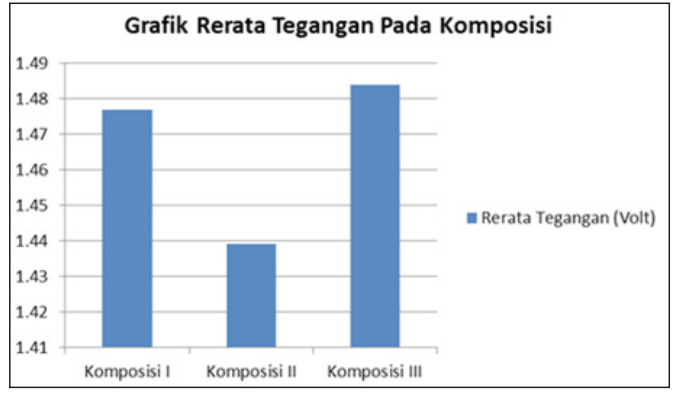

Gambar 11 Grafik Rerata Tegangan Pada Komposisi

Untuk memperoleh rerata tegangan pada komposisi, tegangan total yang dihasilkan kelima baterai akan dibagi dengan lima sehingga diperoleh hasil rerata tegangan pada setiap komposisi dan dapat ditabelkan seperti tabel 4 di bawah ini.

Tabel 4 Rerata Tegangan Pada Komposisi

\begin{tabular}{|c|c|c|c|}
\hline Elektrolit & $\begin{array}{c}\text { Komposisi } \\
\text { I }\end{array}$ & $\begin{array}{c}\text { Komposisi } \\
\text { II }\end{array}$ & $\begin{array}{c}\text { Komposisi } \\
\text { III }\end{array}$ \\
\hline $\begin{array}{c}\text { Rerata } \\
\text { Tegangan (Volt) }\end{array}$ & 1,477 & 1,439 & 1,484 \\
\hline
\end{tabular}

Setelah tabel 4 dibuat maka dapat dibuat juga grafik rerata tegangan pada setiap komposisi baterai seperti pada gambar 11 . Tujuan dibuatnya grafik ini adalah untuk mempermudah pembacaan rerata tegangan pada setiap komposisi baterai.

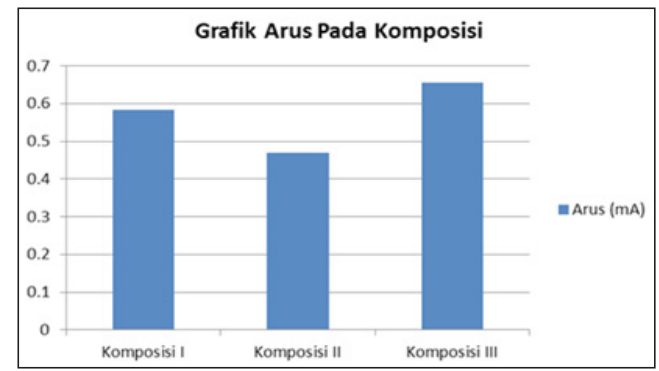

Gambar 12 Grafik Arus Pada Komposisi
Untuk mengetahui besarnya arus listrik pada tiap-tiap komposisi baterai dapat dilakukan dengan cara menghubungkan kutub positif baterai yang terbuat dari batang arang (karbon) dan kutub negatif baterai yang terbuat dari seng. Kabel listrik yang menghubungkan antara kutub positif dan kutub negatif baterai dipasang beban berupa lampu LED. Jika lampu menyala berarti ada arus listrik yang mengalir pada baterai dan dapat diukur menggunakan multimeter digital. Satuan arus listrik menggunakan miliampere $(\mathrm{mA})$. Arus listrik yang mengalir pada beterai pada komposisi I sebesar 0,582 $\mathrm{mA}$, arus listrik yang mengalir pada beterai pada komposisi II sebesar 0,469 mA dan arus listrik yang mengalir pada beterai pada komposisi III sebesar $0,656 \mathrm{~mA}$ seperti yang ditunjukkan pada tabel 5 .

Tabel 5 Arus Pada Komposisi

\begin{tabular}{|c|c|c|c|}
\hline Elektrolit & $\begin{array}{c}\text { Komposisi } \\
\text { I }\end{array}$ & $\begin{array}{c}\text { Komposisi } \\
\text { II }\end{array}$ & $\begin{array}{c}\text { Komposisi } \\
\text { III }\end{array}$ \\
\hline Arus $(\mathrm{mA})$ & 0,582 & 0,469 & 0,656 \\
\hline
\end{tabular}

Setelah tabel 5 dibuat maka dapat dibuat juga grafik arus pada komposisi tiap-tiap baterai seperti pada gambar 12. Tujuan dibuatnya grafik ini adalah untuk mempermudah pembacaan arus listrik pada komposisi.

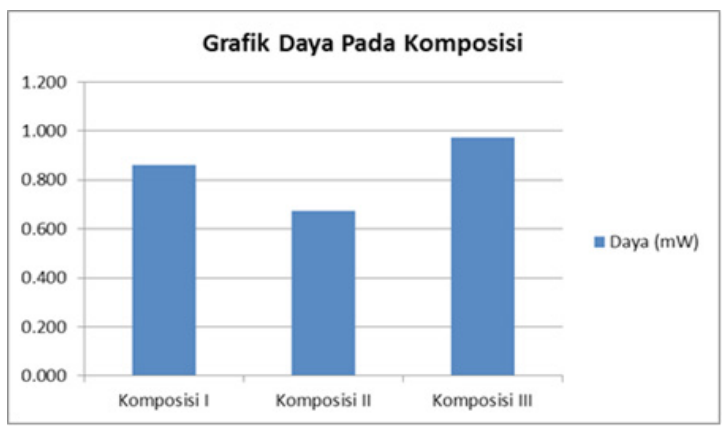

Gambar 13 Grafik Daya Pada Komposisi

Tabel 6 Daya Pada Komposisi

\begin{tabular}{|c|c|c|c|}
\hline Elektrolit & $\begin{array}{c}\text { Komposisi } \\
\text { I }\end{array}$ & $\begin{array}{c}\text { Komposisi } \\
\text { II }\end{array}$ & $\begin{array}{c}\text { Komposisi } \\
\text { III }\end{array}$ \\
\hline Daya $(\mathrm{mW})$ & 0,860 & 0,675 & 0,974 \\
\hline
\end{tabular}

Untuk mengetahui besarnya daya listrik pada tiap-tiap komposisi baterai dapat dilakukan dengan cara mengukurnya menggunakan alat ukur Wattmeter atau menggunakan rumus $\mathrm{P}=\mathrm{V} \times \mathrm{I}$. Satuan daya listrik menggunakan miliWatt $(\mathrm{mW})$. 
Hasil pengukuran daya listrik yang mengalir pada beterai pada komposisi I sebesar $0,860 \mathrm{~mW}$, daya listrik yang mengalir pada baterai pada komposisi II sebesar 0,675 $\mathrm{mW}$ dan daya listrik yang mengalir pada baterai pada komposisi III sebesar 0,974 $\mathrm{mW}$ seperti yang ditunjukkan pada tabel 6. Setelah tabel 6 dibuat maka dapat dibuat juga grafik daya listrik pada komposisi tiap-tiap baterai seperti pada gambar 13. Tujuan dibuatnya grafik ini adalah untuk mempermudah pembacaan daya listrik pada setiap komposisi. Di dalam larutan elektrolit pada komposisi di atas termasuk larutan elektrolit lemah yang dapat diketahui dengan adanya nyala lampu. Basa kuat merupakan senyawa elektrolit lemah. Molekul basa kuat membentuk ion sehingga menghasilkan nyala lampu. Basa kuat mempunyai harga $\mathrm{pH}$ berkisar antara 12-13.

Dari gambar 13 di atas dapat dilihat dengan mudah bahwa daya listrik yang terbesar terdapat pada baterai dengan komposisi III sebesar 0,974 $\mathrm{mW}$. Bawang putih dan bayam merupakan elektrolit dapat memiliki daya hantar listrik karena mengalami ionisasi sempurna jika derajat ionisasinya mendekati satu. Derajat ionisasi adalah perbandingan antara jumlah zat yang mengion dengan jumlah zat yang dilarutkan. Untuk garam tidak terlalu berpengaruh pada daya listrik karena garam bersifat netral yaitu bukan termasuk basa kuat.

\section{Kesimpulan}

Kesimpulan hasil penelitian yang diperoleh, sebagai berikut:

1. Pengaruh elektrolit dari bawang putih sebagai sumber energi listrik alternatif pada baterai kering dapat menghasilkan tegangan 1,42 Volt. Bawang putih termasuk basa kuat sehingga bisa menghasilkan listrik.

2. Pengaruh elektrolit dari bayam yang sudah dihaluskan dapat dijadikan sebagai sumber energi listrik alternatif pada baterai kering karena bayam termasuk basa kuat. Bayam dapat menghasilkan tegangan listrik 1,198 Volt.

3. Pengaruh elektrolit dari garam sebagai sumber energi listrik alternatif pada baterai kering menghasilkan 1,556 Volt. Garam bersifat netral, tidak termasuk basa kuat ataupun asam kuat tetapi dapat menghasilkan tegangan listrik. Garam diberikan sedikit air sehingga berubah menjadi larutan dan dapat digunakan sebagai campuran elektrolit pada baterai.

4. Komposisi campuran terbaik baterai sebagai sumber energi alternatif yang menghasilkan daya listrik terbesar adalah komposisi III. Tegangan yang dihasilkan 1,484 Volt dan arus 0,656 mA sehingga mampu menghasilkan daya $0,974 \mathrm{~mW}$.

\section{Saran}

Saran-saran untuk untuk penelitian lebih lanjut yaitu dengan memakai elektrolit bawang yang masih segar sehingga dapat diperoleh basa yang kuat, kemudian dapat memakai bayam yang segar agar diperoleh basa yang kuat.

\section{Ucapan Terima kasih}

Penulis mengucapkan terima kasih kepada Sekolah Tinggi Teknologi Adisutjipto Yogyakarta yang telah yang telah memberi dukungan finansial terhadap penelitian ini. Juga kepada bagian P3M STTA yang telah membantu tugas dosen untuk melaksanakan salah satu Tridharma perguruan tinggi.

\section{DAFTAR PUSTAKA}

[1]Hasbullah M.T.2009.Dasar konversi energi. Elektrikal engineering dept energy conversion system. FPTK UPI.

[2]Gupta, N. and T.D. Porter. 2001. Garlic and garlicderived compounds inhibit human squalene monooxygenase. Journal of Nutrition 131: 1656-1663.

[3]Banerjee, S. K. and S. K. Maulik. 2002. Effect of garlic on cardiovasculer disorders: a review. Nutrition Journal 1 (4): 1-12.

[4]Jeffery, G.H., Bassett, J., Mendham, J., dan Denney, R.C., 1989. Vogel's Textbook of Quantitative Chemical Analysis. New York: John Wiley \& Sons.

[5]Dahanukar, S.A., R.A. Kulkarni, and N.N. Rege. 2000. Pharmacology of medicinal plants and natural products. Indian Journal of Pharmacology 32: S78-S96. 